\title{
Stranding of Balaenoptera acutorostrata Lacépède, 1804 (Mammalia Cetacea) on the coast of Fregene (Rome, Latium, Italy)
}

\author{
Mauro Grano"*, Riccardo Di Giuseppe², Miriam Paraboschi \& llaria Campana3,4 \\ ${ }^{1}$ Associazione Insieme per il Mare, Via Umberto Lusena 4, 00136 Rome, Italy; email: elaphe58@yahoo.it \\ ${ }^{2}$ Associazione Insieme per il Mare, Via Umberto Lusena 4, 00136 Rome, Italy; email: info@programmanatura.it \\ ${ }^{3}$ Accademia del Leviatano, Via dell'Ospedaletto 53/55, 00054 Maccarese (Rome), Italy; email: mimipara@hotmail.it \\ ${ }^{4}$ Department of Ecological and Biological Sciences, Tuscia University, Borgo Le Saline, 01016 Tarquinia, Viterbo, Italy; email: \\ ilariacampana@unitus.it \\ ${ }^{*}$ Corresponding author, email: elaphe58@yahoo.it
}

\begin{abstract}
The stranding of a juvenile of Minke Whale (Balaenoptera acutorostrata Lacépède, 1804) on the coast of Fregene, near Rome (Latium, Central Italy) is here reported. Historical and recent data suggest the possibility that the Mediterranean Sea could be a potential birth or nursery area for this species.
\end{abstract}

KEY WORDS Cetacea; Balaenopteridae; stranding; Tyrrhenian Sea; Fregene.

Received 23.05.2020; accepted 22.06.2020; published online 30.06.2020

\section{INTRODUCTION}

The Minke Whale (Balaenoptera acutorostrata Lacépède, 1804) is a cosmopolitan species found in all oceans and at all latitudes, from $65^{\circ} \mathrm{S}$ to $80^{\circ} \mathrm{N}$. (Stewart \& Leatherwood, 1985; Arnold et al., 1987; Arnold, 1997). The Minke Whale is a species listed in the Appendix I of the Convention on International Trade in Endangered Species of Wild Fauna and Flora - CITES (except for the population of West Greenland listed in Appendix II) and it is considered a "threatened species" in the Annex II of the Barcelona Convention for Protection against Pollution in the Mediterranean Sea. This species is also included in the Appendix II of the Bern Convention on the Conservation of European Wildlife and Natural Habitats and considered a "Strictly protected fauna species". It is also a "species in need of strict protection" in the European Union by the Annex IV of the Council Directive 92/43/EEC of May 21th 1992 on the conservation of natural habitats and of wild fauna and flora, known as "Habitats Directive". Finally, it is listed as "Vulnerable" at the European level, and classified as "Least Concern" on the IUCN Red List of Threatened Species (Reilly et al., 2008; Maio et al., 2016). In the Mediterranean Sea, according to the Annex 4 of Agreement on the Conservation of Cetaceans of the Black Sea, Mediterranean Sea and Contiguous Atlantic Area (ACCOBAMS), this species is considered as a "visitor species", "occasional" in the Italian seas (Maio et al., 2016).

Balaenoptera acutorostrata has a stockier build than the other species of the Balaenopteridae family, with a triangular head and a narrow, pointed muzzle. The dorsal fin is larger than that of $B$. bonaerensis and is placed in a more advanced position, the pectoral fins are small and lanceolate, and the caudal fin is wide. The coloring of the upper parts is slate gray or dark gray, that of the lower parts is whitish; the dorsal part of the pectoral fins 
is crossed by a white band. The adults of the northern oceans have an average length of $7 / 9$ meters and a weight of almost 5 tons.

\section{MATERIAL AND METHODS}

Fregene, in the Municipality of Fiumicino just 30 $\mathrm{km}$ from Rome in Latium, is a well-known seaside village in the Tyrrhenian Sea. The coordinates are: $41^{\circ} 51^{\prime} 11.08^{\prime \prime} \mathrm{N}-12^{\circ} 11^{\prime} 36.16^{\prime \prime} \mathrm{E}$. The presence of the mouth of the Arrone River, emissary of Bracciano Lake, is significant in the area for the inputs of nutrients and debris at sea. The village of Fregene is part of the Agro Romano area. The whale beaching took place on April 26th 2020, in the area overlooking the "Glauco" beach property. The authorities were notified of the presence of a large cetacean stranding on the beach (Fig. 1). The animal was found to be a juvenile female specimen of $B$. $a c u$ torostrata, 2.5 meters long. An evident prolapse of the tongue, already swollen by the progress of the decomposition process, indicated that, probably, the animal had arrived ashore already dead (Figs. 2, 3).
Currently the causes of death have not been disclosed by the Experimental Zooprophylactic Institute of Latium and Tuscany, which collected biological samples for the analyses required in these cases. The specimen in question could probably be the same that was spotted only a few days earlier inside the harbor of Anzio, on the southern Latium coast.

\section{RESULTS}

\section{Systematics}

Classis MAMMALIA Linnaeus, 1758

Ordo CETACEA Brisson, 1762

Subordo MYSTICETI Cope, 1891

Familia BALAENOPTERIDAE

Genus Balaenoptera Lacépède, 1804

Balaenoptera acutorostrata Lacépède, 1804

The historical data from 1771 to 2016 revealed 49 records of stranded or caught $B$. acutorostrata in the Mediterranean Sea (Cagnolaro et al., 2014).

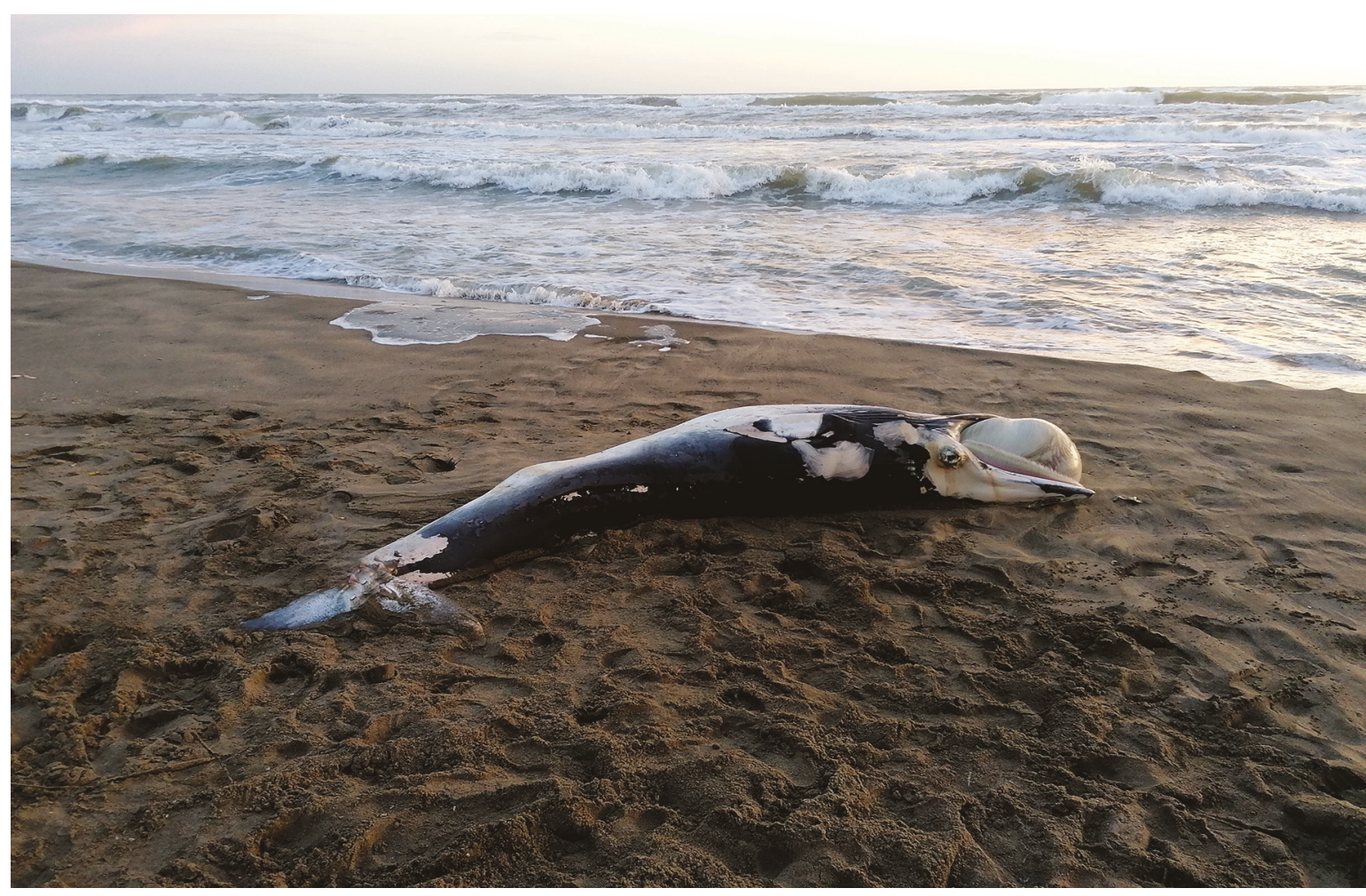

Figure 1. Balaenoptera acutorostrata on ther coast of Fregene (Thyrrenian Sea, Italy). 


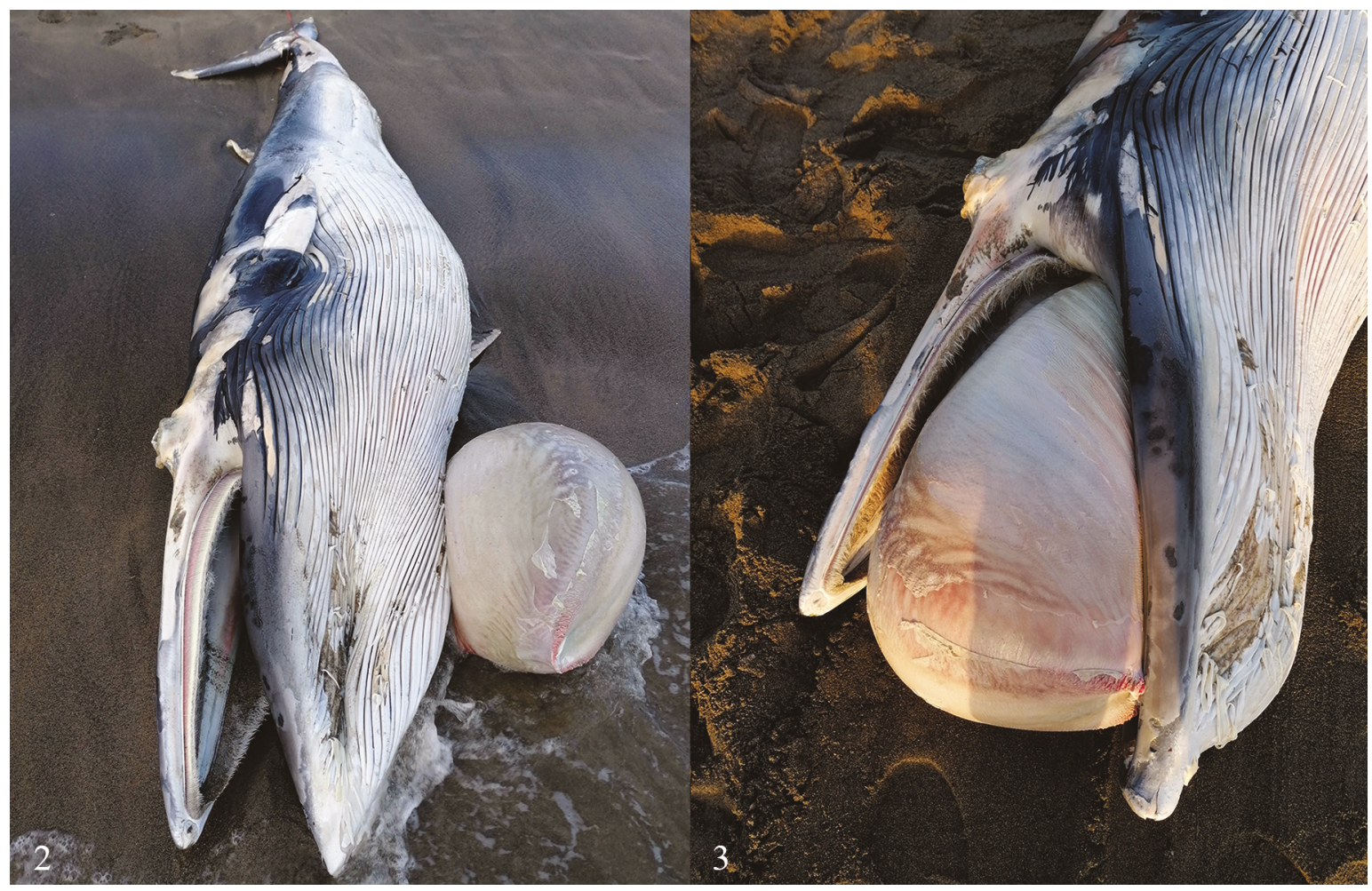

Figures 2, 3. Balaenoptera acutorostrata on ther coast of Fregene (Thyrrenian Sea, Italy).

Fifteen of the 49 records were represented by young individuals, less than 4 meters long (Maio et al., 2016). Mitochondrial DNA analyses performed on a young specimens of the same species stranded in 2010 on the Salerno coast revealed that the whale had a haplotype identical to that of the North Atlantic populations (Maio et al., 2016). This data, also supported by the significant share of young specimens that have been found in the Mediterranean Sea, suggests that our seas are likely to be used to give birth and as a nursery area to the lesser whales of the Atlantic.

\section{REFERENCES}

Arnold P., 1997. Occurrence of dwarf minke whales (Balaenoptera acutorostrata) on the Northern Great Barrier Reef, Australia. Report of the International Whaling Commission, 47: 418-424.

Arnold P., Marsh H., Heinsohn G., 1987. The occurrence of two forms of minke whales in east Australian waters with a description of external characters and skeleton of the diminutive or dwarf form. The Scien- tific Report of the Whales Research Institute, Tokyo, 38: $1-46$.

Cagnolaro L., Maio N. \& Vomero V. (Eds.), 2014. The cetacean collections of Italian Museums. First part (living Cetaceans). Museologia Scientifica, Memorie 12/2014: 1-420.

Maio N., Giovannotti M., Caputo Barucchi V., Petraccioli A., Pollaro F., Guarino F.M., Splendiani A., De Stasio R. \& Odierna G., 2016. Haplotype characterization of a stranded Common Minke Whale calf (Balaenoptera acutorostrata Lacépède, 1804): is the Mediterranean Sea a potential calving or nursery ground for the species? Hystrix, the Italian Journal of Mammology. https://doi.org/10.4404/hystrix-27.211661

Reeves R.R., Smith B.D., Crespo E.A. \& Notarbartolo di Sciara G., 2003. Dolphins, whales and porpoises: 2002-2010. Conservation Action Plan for the World's Cetaceans. IUCN/SSC Cetacean Specialist Group, Gland, Switzerland and Cambridge, 139 pp.

Reilly S.B., Bannister J.L., Best P.B., Brown M., Brownell R.L. Jr., Butterworth D.S., Clapham P.J., Cooke J., Donovan G.P., Urbán J. \& Zerbini A.N., 2008. Balaenoptera acutorostrata. The IUCN Red List of Threatened Species. Version 2015.3. http:// www.iucnredlist.org. 
Stewart B.S. \& Leatherwood S., 1985. Minke whale Balaenoptera acutorostrata Lacépède 1804. In: Ridgway S. \& Harrison R. (Eds.), Handbook of marine mammals. v.3. The Sirenians and Baleen Whales, Academic Press, San Diego, pp. 91-136.
Zerbini A.N. \& Simões-Lopes P.C., 2000. Morphology of the skull and taxonomy of southern hemisphere minke whales. Scientific Committee, 52nd Meeting of the International Whaling Commission, Adelaide, $28 \mathrm{pp}$. 